This article was downloaded by: [Memorial University of Newfoundland]

On: 31 J anuary 2015, At: 00: 33

Publisher: Routledge

Informa Ltd Registered in England and Wales Registered Number: 1072954

Registered office: Mortimer House, 37-41 Mortimer Street, London W1T

3J H, UK

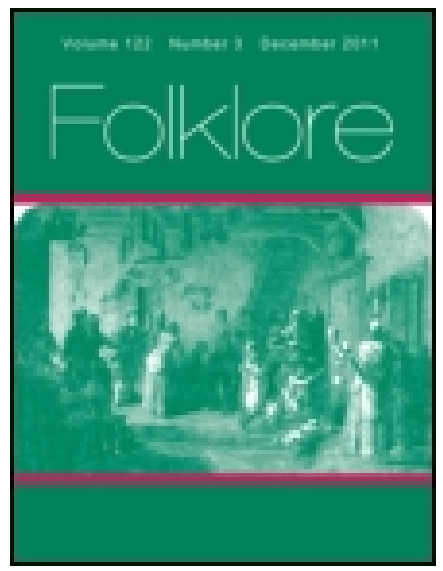

\title{
Folklore
}

Publication details, including instructions for authors and subscription information:

http:// www. tandfonline.com/loi/ rfol20

\section{The Bull-Roarer in Ceylon.}

C. G. Seligmann

Published online: 06 Feb 2012.

To cite this article: C. G. Seligmann (1900) The Bull-Roarer in Ceylon., Folklore, 11:4, 456-456, DOI: 10.1080/0015587X.1900.9719598

To link to this article: http:// dx. doi. org/ 10.1080/0015587X.1900.9719598

\section{PLEASE SCROLL DOWN FOR ARTICLE}

Taylor \& Francis makes every effort to ensure the accuracy of all the information (the "Content") contained in the publications on our platform. However, Taylor \& Francis, our agents, and our licensors make no representations or warranties whatsoever as to the accuracy, completeness, or suitability for any purpose of the Content. Any opinions and views expressed in this publication are the opinions and views of the authors, and are not the views of or endorsed by Taylor \& Francis. The accuracy of the Content should not be relied upon and should be independently verified with primary sources of information. Taylor and Francis shall not be liable for any losses, actions, claims, proceedings, demands, costs, expenses, damages, and other liabilities whatsoever or howsoever caused arising directly or indirectly in connection with, in relation to or arising out of the use of the Content.

This article may be used for research, teaching, and private study purposes. Any substantial or systematic reproduction, redistribution, reselling, loan, sub-licensing, systematic supply, or distribution in any form to anyone is 
expressly forbidden. Terms $\&$ Conditions of access and use can be found at http://www.tandfonline.com/page/terms-and-conditions 
drinking $i t$, and then pretended to fall asleep. When she went off, he took a revolver and sword and followed her. She told the negro, "See what has happened to me; my eye is gone. Now you won't care for me any more." But her lover said, "You are. always the same to me; but why are you so late?" Then they began to toy with each other. Then her husband shot them both with his revolver through the crevice, and breaking open the door hacked off their heads.

W. R. Paton.

\section{The Bull-Roarer in Ceylon.}

When recently in Ceylon, Mr. A. Haly, Director of the Colombo Museum, told me that he' had seen Singalese children whirling a thin slat of wood round their heads whilst at play, so producing a whirring noise. I subsequently saw them doing this, and was able to procure specimens from Cotta, a small village about three miles from Colombo.

The slat of wood is roughly quadrilateral, not tapered at either end, about $137 \mathrm{~mm}$. long by $40 \mathrm{~mm}$. broad. There is a hole near one end, through which is passed a piece of string, which is prevented from slipping through by a knot at the end, the other extremity being tied to a short stiff stick about 50 centimetres in length. In using the toy the stick is waved to and fro above the head, not whirled round in continuous circles as is done in New Guinea. . I was informed that at Colombo a troop of boys whirling these toys, called runa, followed the Perahera procession (a ceremony in the great Buddhist festival held annually about the end of May). This is not done at Kandy, their place being taken by boys' cracking whips. As far as I could ascertain, the bull-roarer is not used by Tamil children. Subsequently I saw neater specimens, made of bamboo, used as toys at Anuradhapura, about 150 miles from Colombo.

C. G. SeligmanN.

\section{Cropping Animals' Ears.}

$$
\text { (Cf. p. 380.) }
$$

In Asia Minor it is customary to cut the ears of the large and savage breed of dogs used as boar-hounds, and for protecting the flocks from wolves. The flap of the ear is cut off, roasted, and given to the puppy to eat. This is supposed to make it more 